\title{
EDITORIAL
}

\section{COVID 19 and The New Normal}

Syed Muhammad Imran Majeed, Rehma Ahsan Gilani

The world is waking up to a new reality where an invisible enemy has made human contact contagious and exposed the long-hidden fault line of verisimilitude, blurring the lines between reality and paranoia. The global reaction is unprecedented with world economy virtually at a standstill. The economic fallout of the outbreak could trigger a recession of unparalleled scale. But is economics the only challenge? The pandemic is attacking societies at their core. The author of Sapiens, Yuval Noah Harari puts it well when he writes "The biggest danger is not the virus itself. Humanity has all the scientific knowledge and technological tools to overcome the virus. The really big problem is our own inner demons, our own hatred, greed and ignorance". ${ }^{1}$ Editor-in-chief The Lancet, Richard Horton voiced similar concerns while noting that the discussion of COVID-19 pandemic has been interpreted as a part of the geopolitical struggle of nations. ${ }^{2}$ Beyond the crisis and tragedy that COVID-19 has brought on humanity, it has made universal behavior change in societies. Can preventive measures become new social norm? The insights of social and behavioral sciences including work on navigating threats, social and cultural influences on behavior, science communication, moral decision-making, leadership, and stress ${ }^{3}$ can $^{2}$ provide guidance to help align human behavior with the recommendations of epidemiologists and public health experts.

Another factor undermining health and welfare around the globe are major gaps in public health investment. Tedros Adhanom Ghebreyesus, at World Health Organization (WHO) May $6^{\text {th }}$ media briefing ${ }^{4}$, underscored the importance of quality of health care at baselineas this forms the foundation of global health security. But this is much more than a health crisis. It is a human crisis. According to one estimate from the $\mathrm{UN}^{5}$, more than five billion people will lack access to essential health services including access to a health worker, essential medicines and running water in hospitals, by 2030. This issue is further complicated by a shortage of trained healthcare workers. ${ }^{6}$

So, what is the answer to this predicament? The Imperial College Covid-19 Response Team, led by Neil Ferguson", concluded that short term "suppression" of the public health impact of Covid-19 is possible, through a series of "lockdowns", each one lasting a short period of time, followed by a relaxation, followed by the inevitable spike in infections and critical care cases, followed by another lockdown. A similar idea has been presented by Uri Alon and his colleagues at Tel Aviv University, with the title Adaptive Cyclic Exit Strategies ${ }^{8}$ used mathematical models to show that a cyclic schedule can, in certain conditions, suppress the epidemic.

The truth is that the normal is dead and the new normal is going to stay in one form or another for a very long time to come. Pakistan will need to make difficult decisions to balance the demands of responding directly to COVID-19, while simultaneously engaging in strategic planning and coordinated action to maintain essential health service delivery including adequate equipment, trained staff and test-track-and-quarantine operations (TTQs), to manage the virus' spread regardless of its transmission phase. mitigating the risk of system collapse.

Two points need emphasis. Firstly, understanding the process of development of human immunity against viruses and adaptation of immunity enhancing measures by all. Secondly, the term social distancing should be replaced with the term physical distancing as the connotation of the former is misleading. In these hard times, "social connectedness" is important not only for mental health and wellbeing but communities that survive and rebuild most effectively after disasters are the ones with strong cohesions and social networks.

Editor-in-Chief

doi: https://doi.org/10.37185/LnS.1.1.120 


\section{REFERENCES}

1. https://www.dw.com/en/virus-itself-is-not-the-biggest-danger-says-yuval-noah-harari/a-53195552

2. https://news.cgtn.com/news/2020-05-01/Useless-incorrect-to-blame-China-for-COVID-19-origin-Lancet-expert-Q93Dwq FYlg/index.html

3. Bavel, J.J.V., Baicker, K., Boggio, P.S. et al. Using social and behavioral science to support COVID-19 pandemic response. Nat Hum Behav (2020). https://doi.org/10.1038/s41562-020-0884-z

4. https://www.weforum.org/agenda/2020/05/covid-19-reveals-gaps-in-public-health-system-who-briefing/

5. Primary Health Care on the Road to Universal Health Coverage 2019 Global Monitoring Report https://www.who.int/healthinfo/universal_health_coverage/report/uhc_report_2019.pdf

6. https://www.un.org/sites/un2.un.org/files/sg_report_socioeconomic_impact_of_covid19.pdf

7. Ferguson, N. M. et al. Preprint at Spiral https://doi.org/10.25561/77482 (2020)

8. https://www.medrxiv.org/content/10.1101/2020.04.04.20053579v4.article-metrics 